\title{
Teoria (literatury) to było coś innego. Z Profesor Teresą Cieślikowską rozmawia Irena Hübner
}

Irena Hübner: Wiem, że nie jest Pani Profesor rodowitą łodzianką. Kiedy przyjechała Pani do Łodzi?

Teresa Cieślikowska: To było już po wojnie. Dotarłam do Łodzi po tułaczce, która zaczęła się jeszcze w 1939 roku. Zaraz też zaczęłam szukać sobie liceum dla dorosłych, bo jeszcze podczas wojny uczyłam się, często sama, kiedy tylko miałam okazję i znalazłam jakieś podręczniki, ale także korzystając z tajnych kompletów, na których ukończyłam półtorej klasy, gdy przez jakiś czas przebywałam w Kieleckiem. Tak więc w Łodzi pierwszą licealną rozpoczęłam od półrocza. W końcu zdałam maturę, ale po jakimś czasie okazało się, że w mojej szkole było bardzo dużo nadużyć, fałszerstw, musiałam weryfikować moje świadectwo maturalne. Niedawno widziałam to poświadczenie, bo przygotowując biogram przeglądałam pisma, których stosy tutaj. Potem przez kilka lat mieszkałam, pracowałam w różnych instytucjach i studiowałam w Łodzi.

IH: To były studia zaoczne czy stacjonarne?

TC: Stacjonarne, ale dla osób, które pracowały stworzono możliwość studiowania. Obowiązywał nas inny tryb nauczania, na przykład mieliśmy chyba dziesięć godzin zajęć w tygodniu.

IH: Które to były lata, kiedy Pani podjęła studia?

* Teresa Cieślikowska - prof. dr hab., emerytowany pracownik Uniwersytetu Łódzkiego. Wieloletni kierownik Katedry Teorii Literatury oraz dyrektor Instytutu Teorii Literatury, Teatru i Filmu UŁ. Teoretyk literatury, badaczka powieści nowoczesnej, zainteresowana też korespondencją sztuk oraz relacjami międzykulturowymi. Autorka monografii: Pisarstwo Teodora Parnickiego (Warszawa 1965), Warsztat współczesnej prozy narracyjnej: wybrane zagadnienia (Łódź 1967), U podstaw prozy artystycznej XX wieku (Łódź 1970). Autorka wielu artykułów naukowych, których tematykę zwięźle ujmuje tytuł Jej książki W kręgu genologii, intertekstualności, teorii sugestii (Łódź 1995). Wieloletni redaktor serii naukowej „Folia Scientiae Artium et Litterarum”. 
TC: Rozpoczęłam w 1947 roku. Wtedy jeszcze nie było egzaminów wstępnych i najpierw zgłosiłam się na bibliotekoznawstwo, w takim dziecięcym przekonaniu, że będę miała dobry kontakt z książkami. Było to złudzenie, te studia nie spełniały moich oczekiwań, powiem nawet, że znudziły mnie po prostu. Jedyne zajęcia, które mnie interesowały, to były wykłady profesora Muszkowskiego ${ }^{1}$. Ponieważ podejmowały zagadnienia dotyczące historii pisma, także i książki, to właśnie zachęciło mnie do przejścia na polonistykę, którą ukończyłam w 1952 roku.

IH: A kto wtedy wykładał na polonistyce?

TC: Pamiętam wykłady profesora Wallisa², na które chodziłam. Oczywiście profesor Skwarczyński ${ }^{3}$. Na seminarium byłam u profesora Adamczewskiego ${ }^{4}$. Ja go bardzo nie lubiłam, to był taki zgryźliwy starzec, ale nic dziwnego, bo mu strasznie komuniści dokuczali. U niego skończyłam seminarium historycznoliterackie, potem już chodziłam na teoretycznoliterackie. Był jeszcze profesor Boleski ${ }^{5}$, historyk literatury, i dwóch innych polonistów, których w tej chwili nie pamiętam. Chodziłam też na wykłady $\mathrm{z}$ historii, ale trochę zniechęcające było w nich to, że wykładowca je czytał. Wybrałam również zajęcia z filozofii i jeszcze coś... u profesor Kotarbińskiej $^{6}$ - ćwiczenia z logiki, bardzo mnie one interesowały. Uczęszczałam także do profesora Sznaydera ${ }^{7}$, klasycysty.

\section{IH: To też wielkie nazwisko...}

TC: Filozofię wykładał profesor Legowicz ${ }^{8}$.

IH: Rzeczywiście, same ówczesne lub późniejsze sławy...

1 Prof. Jan Muszkowski (1882-1953), bibliotekarz i bibliotekoznawca, współorganizator Uniwersytetu Łódzkiego (1945) i założyciel (w roku 1945; do 1953 kierownik) pierwszej w Polsce Katedry Bibliotekoznawstwa.

2 Prof. dr Mieczysław Wallis (1895-1975), filozof, estetyk i historyk sztuki. Profesor UŁ (tu kierował Katedrą Historii Sztuki) i PWST w Warszawie.

3 Prof. dr Zdzisław Skwarczyński (1914-1987), filolog, specjalista z zakresu literatury oświecenia. Od 1952 r. zatrudniony w Katedrze Historii Literatury Polskiej UŁ. Dyrektor Instytutu Filologii Polskiej w latach 1970-1978. Prodziekan (1952-1953) oraz dziekan Wydziału Filologicznego UŁ (1953-1955). Rektor UŁ w latach 1969-1972.

4 Prof. dr Stanisław Adamczewski (1883-1952), historyk literatury polskiej, badacz twórczości S. Żeromskiego i J. Kochanowskiego. Współorganizator i kierownik Katedry Historii Literatury Polskiej na Wydziale Humanistycznym UŁ. W 1950 r. odsunięty od prowadzenia zajęć dydaktycznych i przeniesiony w stan spoczynku, prawdopodobnie wskutek ideologicznych sporów prowadzonych ze środowiskiem marksistów skupionych w Łodzi wokół „Kuźnicy”.

5 Prof. dr Andrzej Boleski (1877-1965), historyk literatury (zwłaszcza romantycznej) i krytyk. W latach 1945-1948 kierownik Katedry Literatury Polskiej na Wydziale Humanistycznym UŁ.

6 Prof. Janina Kotarbińska (1901-1997), filozof i logik, zajmowała się logiką współczesną oraz teorią znaku. W latach 1945-1951 profesor Uniwersytetu Łódzkiego. Prywatnie żona profesora Tadeusza Kotarbińskiego.

7 Prof. dr Jerzy Schnayder (1891-1974), filolog klasyczny, profesor nadzwyczajny Uniwersytetu Łódzkiego, potem profesor zwyczajny Uniwersytetu Wrocławskiego, kierownik Katedry Filologii Klasycznej Uniwersytetu Łódzkiego w latach 1946-1953.

8 Prof. dr Jan Legowicz (1909-1992), filozof i historyk filozofii, specjalista w zakresie filozofii starożytnej i średniowiecznej. W latach 1948-1953 wykładowca historii filozofii na Uniwersytecie Łódzkim, od 1953 r. związany z Uniwersytetem Warszawskim. 
TC: To byli chyba wszyscy moi wykładowcy. Choć nie, przypomniałam sobie, że ćwiczenia prowadził wtedy też profesor Dejna ${ }^{9} \ldots$

IH: No tak, nie pytałam o jezykoznawców, bo myślałam, że Pani Profesor od początku studiów polonistycznych skłaniała się ku literaturoznawstwu.

TC: Mnie językoznawstwo nudziło, ale trudno, trzeba było jednak realizować pewien program, mimo że miałam też sporo swobody. Mogłam sobie wybierać przedmioty, wykładowców, do pewnego stopnia oczywiście, ale nie było bardzo rygorystycznych zasad. Obowiązkowe były na przykład wykłady ze staro-cerkiewno-słowiańskiego, tłumy pamiętam w auli naprzeciwko rektoratu, po drugiej stronie Narutowicza. Potem zdawałam egzamin z tego przedmiotu, nie tylko kolokwia. Prowadził to znany, głośny w Łodzi profesor Ułaszyn ${ }^{10}$. To był chyba także ukrainista z wykształcenia. Pamiętam go, jak kroczył ulicą Narutowicza w kapeluszu, z laską zawieszoną na rondzie tego kapelusza.

Tak wyglądał ten etap studiów. Po południu uczelnia, a codziennie od ósmej praca w Państwowym Instytucie Książki, który prowadził doktor Adam Łysakowski1 ${ }^{11}$. Miałam tam nudne zadania...

IH: Pamiętam, jak Pani Profesor opowiadała o tym kiedyś.

TC: Kończyłam o trzeciej i szłam na zajęcia, do domu wracałam wieczorem.

IH: Zajęcia dla studiów dziennych odbywały się też po południu?

TC: Tak, wiele osób wtedy łączyło studiowanie i pracę.

IH: A co skłoniło Panią Profesor do tego, żeby zainteresować się teorią?

TC: Bardzo zaciekawiły mnie wykłady profesor Skwarczyńskiej ${ }^{12}$. Chodziłam także na ćwiczenia doktora Trzynadlowskiego ${ }^{13}$. I tak zostało,

9 Prof. dr Karol Dejna (1911-2004), twórca łódzkiej szkoły dialektologii polskiej. Pierwszy dziekan Wydziału Filologicznego UŁ (od roku akad. 1951/52). Redaktor czterotomowego Atlasu gwar polskich (1998-2002).

10 Prof. Henryk Ułaszyn (1874-1956), językoznawca, slawista, autor ponad tysiąca rozpraw o bardzo zróżnicowanej tematyce. Od 1945 r. do śmierci profesor Uniwersytetu Łódzkiego.

11 Dr hab. Adam Łysakowski (1895-1952), bibliotekarz i bibliotekoznawca, wykładowca uniwersytecki, dyrektor Państwowego Instytutu Książki w Łodzi (1946-1949) i Instytutu Bibliograficznego Biblioteki Narodowej w Warszawie (od 1949 r.).

12 Prof. dr hab. Stefania Skwarczyńska (1902-1988), teoretyk i historyk literatury oraz teatru. Doktorat uzyskała w 1925 r. W 1937 r. na podstawie monografii Teoria listu otrzymała pierwszą w Polsce habilitację z dziedziny teorii literatury, mianowana profesorem zwyczajnym w 1957 r. Z Łodzią związana od 1932 r. (uczyła w Gimnazjum im. E. Orzeszkowej i Pedagogium), w 1939 r. miała objąć Katedrę Historii i Teorii Literatury w Wolnej Wszechnicy Polskiej (oddział łódzki). Po wojnie wróciła do Łodzi, gdzie współorganizowała Uniwersytet Łódzki oraz założyła w nim Katedrę Teorii Literatury (1945), którą kierowała do czasu jej likwidacji w 1950, a także po jej reaktywacji (1958) aż do jej przekształcenia w 1973 r. w Instytut Teorii Literatury, Teatru i Filmu (którego dyrektorem była przez kilka miesięcy w 1973 r.). Założycielka pisma „Zagadnienia Rodzajów Literackich” (1958). Pomysłodawczyni i organizatorka studiów kulturoznawczych na UŁ.

13 Prof. dr hab. Jan Trzynadlowski (1912-1995), teoretyk i historyk literatury, teoretyk filmu, wydawca. Pracownik UŁ w latach 1945-1950. W latach 1956-1960 pełnił funkcję dyrektora i redaktora naczelnego wydawnictwa Ossolineum. Od 1951 r. związany z Uniwersytetem 
ponieważ inne wykłady - i Boleskiego, i Adamczewskiego, były dla mnie niezbyt interesujące. Teoria to było coś innego.

\section{IH: A z czego pisała Pani pracę magisterską?}

TC: Właśnie, to moja pierwsza drukowana praca. Był konkurs prac magisterskich, w którym dostałam wyróżnienie. Tekst został potem opublikowany w „Pracach Polonistycznych”. Fatalny tytuł: Porównanie pierwszego i trzeciego wydania "Sztuki rymotwórczej", z którego od dawna nie byłam zadowolona. Próbowałam w tej pracy interpretacji marksistowskiej.

IH: Czy nie wszyscy młodzi ludzie wtedy tak pisali, trochę pod wpływem swych mentorów, trochę ze względu na - pozwolę sobie zażartować - „konieczność dziejową"?

TC: Raczej nie wszyscy. Miałam koleżankę, z którą pisałyśmy wspólnie pracę dotyczącą bibliografii na ćwiczeniach u Adamczewskiego. Ona miała zupełnie inne nastawienie. To ja byłam wtedy tak ukierunkowana. Nie mogę powiedzieć, że skrajnie, ale byłam. Moje koleżanki, na przykład Inka Brodzka ${ }^{14}$, były rozsądnie, rozsądniej w każdym razie, nastawione. Inkę przy pominam, bo to była moja najlepsza koleżanka. Doznałam od niej zresztą i później wiele serdeczności.

\section{IH: I co potem, Pani Profesor, po studiach?}

TC: Wciąż gdzieś tam pracowałam. Proszę sobie wyobrazić, że w całym tym okresie zmieniałam pracę aż siedem razy - z rożnych wprawdzie, ale zawsze niezależnych ode mnie powodów. Zlikwidowano na przykład Państwowy Instytut Książki. I obowiązywał przecież tzw. „nakaz pracy”, narzucający absolwentom uczelni wyższych zatrudnienie na określonych stanowiskach i we wskazanych firmach. Ja zaczęłam od Urzędu Likwidacyjnego ${ }^{15}$, po prostu tam dostałam pracę na kilka miesięcy. Potem byłam zatrudniona między innymi w Szkole Filmowej, przez chyba dwa lata, w bibliotece. Przez jakiś czas robiłam korektę w „Ekspresie”. Musiałam jeździć na noc, praca zaczynała się o dziesiątej wieczorem. Pracowników podwożono. Kończyło się o piątej. To było już w okolicach roku 1953, byłam już wtedy po ślubie.

Ponieważ mąż $\dot{z}^{16}$ nie mógł nigdzie dostać pracy, składał podania w kilkudziesięciu instytucjach, zawsze chętnie go przyjmowano, ale potem okazywało się, że pracy nie ma ${ }^{17}$, był zmuszony jechać tam, gdzie go

Wrocławskim. Tytuł profesora otrzymał w 1966 r. Współtwórca i redaktor naczelny (19891995) czasopisma „Zagadnienia Rodzajów Literackich”.

14 Prof. dr hab. Alina Brodzka-Wald (1929-2011), historyk literatury (zwłaszcza polskiej literatury XX w., znawczyni zagadnień realizmu), wieloletni (1950-2011) pracownik Instytutu Badań Literackich Polskiej Akademii Nauk. W latach 1979-1992 kierowała zespołem redakcyjnym Stownika literatury polskiej XX wieku.

${ }^{15}$ Główny Urząd Likwidacyjny (i urzędy administracyjnie mu podległe) zajmował się szacowaniem wartości i sprzedażą majątków opuszczonych przez dawnych, zwykle jeszcze przedwojennych, właścicieli. Istniał w latach 1946-1951.

16 Sławomir Cieślikowski, psycholog, znawca kultury i literatury indyjskiej.

17 Sławomir Cieślikowski zaraz po wojnie, mieszkając i ucząc się w Łodzi (tu w 1946 zdał maturę i zapisał się na studia), został członkiem konspiracyjnej organizacji „Wolność i Niezawisłość". Aresztowany w 1950 r. przez Urząd Bezpieczeństwa, po zwolnieniu z więzienia (m.in. na Rakowieckiej w Warszawie) ukończył wprawdzie studia, ale w wyniku trwających nadal represji pracy w Łodzi otrzymać nie mógł. 
w końcu zatrudniono, a dostał posadę psychologia klinicznego w szpitalu klinicznym w Stroniu Śląskim, tam się przenieśliśmy. Wreszcie mieliśmy do użytku mieszkanie, bo tutaj, w Łodzi, musieliśmy je wynajmować. Ze Stronia nie od razu wróciliśmy do Łodzi, wcześniej pojechaliśmy jeszcze do Wrocławia. Po drodze nas okradziono, choć nie mieliśmy wiele... Mieszkaliśmy $\mathrm{w}$ domu jeszcze podstemplowanym, nie odremontowanym po wojnie, będącym w gestii ZLP. Ale za to w centrum miasta, niedaleko ulicy Szewskiej, prowadzącej do uniwersytetu. Pracowałam wtedy we Wrocławskim Towarzystwie Naukowym i w Państwowym Wydawnictwie Naukowym. To było ciekawe, bo w jednym miałam etat, w drugim wykonywałam obowiązki zawodowe. W każdym razie zatrudniona byłam we Wrocławskim Towarzystwie Naukowym. Od tamtych czasów ciepło wspominam prof. Floryana $^{18}$, który bardzo ułatwił mi wówczas odnalezienie się w obcym dla mnie środowisku. Byłam więc we Wrocławiu kilka lat, ale parę miesięcy po urodzeniu syna przeniosłam się z nim do Łodzi, pamiętam, że poleciałam samolotem.

IH: $\mathrm{O}$, proszę! Nie przypuszczałam, że było to możliwe.

TC: Tak, ale... z drugiej strony, proszę sobie wyobrazić, żeby w Łodzi dostać mieszkanie, musiałam mieć protekcję. A ponieważ wkrótce po tym, kiedy przeniosłam się do Łodzi, czyli w roku 1958, zaczęłam pracę w Katedrze Teorii Literatury, odzyskanej przez profesor Skwarczyńską, pani profesor zwróciła się w mojej sprawie do ówczesnej sekretarz komitetu PZPR - Tatarkówny ${ }^{19}$, uzyskując dla mnie zgodę na kupienie mieszkania. Natomiast mąż został we Wrocławiu i jeszcze długo nie dostawał pozwolenia na powrót do Łodzi.

IH: Przedziwne te nasze powojenne losy, dramatyczne... Wróćmy jednak, jeśli Pani Profesor pozwoli, do spraw zawodowych. Jak doszło do tego, że zaczęła Pani pracować w katedrze profesor Skwarczyńskiej?

TC: Jeszcze we Wrocławiu byłam w kontakcie z profesorem Trzynadlowskim, kiedy był dyrektorem Ossolineum, a jednocześnie cały czas współpracował z profesor Skwarczyńską. Odwiedziłam go w Ossolineum. Nie pamiętam wprawdzie, o czym rozmawialiśmy, ale potem wysłałam pani profesor taki artykulik noszący tytuł $Z$ teza czy bez tezy?, dotyczący zagadnienia tendencyjności w powieści. Zresztą niedawno go odnalazłam, $\mathrm{z}$ bardzo sympatycznym i miłym listem pani profesor Skwarczyńskiej, bardzo podbudowującym.

IH: Imponuje mi to, że będąc we Wrocławiu, z dala od łódzkiego środowiska naukowego, napisała Pani Profesor teoretycznoliteracki artykuł $\mathrm{z}$ własnej inicjatywy i chęci. Musiała ta problematyka Panią naprawdę pociągać.

TC: Ja już tego nie pamiętam, być może miałam jakąśs sugestię od Pani Profesor...

18 Prof. Władysław Floryan (1907-1991), historyk literatury, profesor Uniwersytetu Wrocławskiego, wydawca dzieł pisarzy polskich, redaktor monumentalnego opracowania Dziejów literatur europejskich.

19 Michalina Tatarkówna-Majkowska (1908-1986), do 1927 r. działaczka komunistyczna, w latach 1953-1964 I sekretarz Komitetu Wojewódzkiego PZPR w Łodzi. 


\section{IH: Czy ten tekst został opublikowany?}

TC: Nie, wydrukowana została tylko praca magisterska.

IH: Profesor Skwarczyńska w 1958 roku, czyli akurat wtedy, kiedy Pani podjęła pracę, zainicjowała "Zagadnienia Rodzajów Literackich"20. Czy Pani została włączona w prace redakcji? Czy ona robiła to sama? Pytam, ponieważ widziałam niedawno kilka teczek i szufladek katalogowych ledwo mieszczących zapiski, plany, hasła do Słownika rodzajów i gatunków literackich i listy - wszystko pisane wyłącznie ręką profesor Skwarczyńskiej.

TC: Nie, nigdy nie byłam w redakcji, robiła to ona i profesorowie Trzynadlowski i Ostrowski ${ }^{21}$. Złożono mi taką propozycję, ale nie chciałam jej przyjąć, bo byłam nadzwyczaj świadoma tego, że nie podołam - z jednej strony fizycznie (dzieci rosły, a wraz z nimi liczba domowych, rodzinnych obowiązków), z drugiej - z powodu rodzaju redakcyjnych zadań. „Zagadnienia" to od początku było czasopismo międzynarodowe, oparte na ogromnej ilości korespondencji, tam ciągle trzeba było korespondować, a ja nie lubię pisania listów. Dla mnie każdy list był problemem.

\section{IH: Ale pisała Pani Profesor hasła do Słownika ${ }^{22}$ ?}

TC: Tak, opracowałam kilka haseł, są w Stowniku ${ }^{23}$ wydanym przez Słowinię $e^{24}$ i Grzegorza ${ }^{25}$. Miałam nawet kiedyś nieprzyjemną historię, kiedy

20 Czasopismo (półrocznik) powołane w 1958 r. w Łódzkim Towarzystwie Naukowym przez profesorów Uniwersytetu Łódzkiego Stefanię Skwarczyńską i Witolda Ostrowskiego oraz profesora Uniwersytetu Wrocławskiego Jana Trzynadlowskiego. Wychodzi nieprzerwanie do dziś. Trzon redakcji tworzą od samego początku pracownicy Katedry Teorii Literatury Instytutu Kultury Współczesnej (dawniej Instytutu Teorii Literatury, Teatru i Sztuk Audiowizualnych) Uniwersytetu Łódzkiego. Funkcję redaktora naczelnego pisma pełnili Stefania Skwarczyńska (1958-1988), Jan Trzynadlowski (1989-1995), Grzegorz Gazda (1996-2010) i Jarosław Płuciennik (od 2011). Czasopismo zostało powołane przede wszystkim dla prezentacji problematyki genologicznej w ujęciach badaczy z Polski i z całego świata. Oprócz tego ukazywały się tu również artykuły komparatystyczne i teoretycznoliterackie. Dziś problematyka publikacji została rozszerzona i obejmuje wszelkie zagadnienia literaturoznawcze oraz kulturoznawcze, o ile dotyczą szeroko rozumianych kontekstów literatury. W każdym zeszycie ukazują się też „Materiały do Stownika rodzajów literackich”.

${ }_{21}$ Prof. dr hab. Witold Ostrowski (1914-2006), anglista, tłumacz literatury angielskiej, współtwórca Katedry Filologii Angielskiej w Uniwersytecie Łódzkim (1945) i jej kierownik (1964-1970), w latach 1970-1973 kierownik Instytutu Filologii Obcych, od 1973 - dyrektor Instytutu Filologii Angielskiej.

22 Istotną częścią każdego zeszytu „Zagadnień Rodzajów Literackich” były tzw. „Materiały do Stownika rodzajów literackich", pisane przez specjalistów z całego świata rozbudowane hasła genologiczne, pomyślane jako zaczątek późniejszej samodzielnej publikacji.

23 Gazda Grzegorz, Tynecka-Makowska Słowinia, Słownik rodzajów i gatunków literackich, Kraków 2006.

24 Dr Słowinia Tynecka-Makowska, od lat dziewięćdziesiątych XX w. do 2014 r. adiunkt w Katedrze Teorii Literatury w Instytucie Kultury Współczesnej (d. Instytut Teorii Literatury, Teatru i Filmu) Uniwersytetu Łódzkiego; współredaktor pierwszego wydania Stownika rodzajów i gatunków literackich (Kraków 2006).

25 Prof. dr hab. Grzegorz Gazda, historyk i teoretyk literatury, komparatysta. Autor książek i artykułów poświęconych porównawczym badaniom literatur europejskich XX wieku, zwłaszcza jej nurtów awangardowych, oraz polskiej literaturze międzywojennej. W latach 1987-1991 kierował Zakładem Wiedzy o Filmie i pełnił funkcję Prodziekana Wydziału Filologicznego. Od 1993 kierował najpierw Zakładem Teorii Literatury, następnie Katedrą Teorii Literatury, Teatru i Filmu, a po jej przekształceniu w 2002 w Instytut Kultury Współczesnej pełnił (do 2012) funkcję jego dyrektora, kierując jednocześnie (do 
mieszkający na Śląsku profesor stylistyki napisał, że popełniłam plagiat $\mathrm{w}$ jednym $\mathrm{z}$ tych haseł, w noweli. A ja nowelą zajęłam się najwcześniej ze wszystkich polskich powojennych badaczy. Zarzucił mi, że ściągnęłam jakieś zwroty od Sławińskiego ${ }^{26}$, czym byłam ogromnie zaskoczona, bo wcale nie czytałam akurat tego, co Sławiński napisał o noweli. Kiedy pokazałam to profesor Skwarczyńskiej, ona kazała mi się zwrócić do profesora Zakrzewskiego ${ }^{27}$, który był redaktorem „Pamiętnika Literackiego”. Pomógł. Nie pamiętam, jak to zostało wyjaśnione, w każdym razie udało się, stwierdzono, że nie popełniłam żadnego plagiatu.

IH: A zatem w ‘ 58 roku rozpoczęła Pani pracę w Katedrze Teorii Literatury. Kto jeszcze pracował wtedy z Panią Profesor?

TC: Od początku Jurek Rozental ${ }^{28}$ - i wtedy chyba tylko my dwoje. Kto potem doszedł jako pierwszy? Staszek Kaszyński ${ }^{29}$, teatrolog. Kiedy profesor Skwarczyńska odzyskała swoją katedrę, szefem katedr literaturoznawczych był profesor Dür-Durski ${ }^{30}$ jako historyk literatury. Nie było jeszcze instytutu, tylko zespół katedr.

IH: Państwo, pracownicy Katedry Teorii Literatury, prowadzili zajęcia dydaktyczne na polonistyce. Jak wtedy wyglądał jej program? Jakie miejsce zajmowały poetyka i teoria?

TC: W planie studiów były zajęcia z poetyki i stylistyki, takie ćwiczenia prowadziłam. Ile to lat trwało? Na pewno do doktoratu, czyli do 1964 roku. Pamiętam, na tych zajęciach bywała późniejsza przewodnicząca łódzkiej Platformy Obywatelskiej, Iwona Śledzińska-Katarasińska ${ }^{31}$. Tych osób na ćwiczeniach bywało sporo, jeszcze nie było konwersatoriów, o ile pamiętam. Może pojawiały się dopiero na późniejszych latach?

2014) Katedrą Teorii Literatury i Pracownią Języka i Kultury Żydowskiej (2005-2014). Pomysłodawca i współredaktor pierwszego wydania Słownika rodzajów i gatunków literackich (Kraków 2006), redaktor Stownika rodzajów i gatunków literackich. Nowe wydanie (Warszawa 2011).

26 Prof. dr hab. Janusz Sławiński (1934-2014), teoretyk i historyk literatury, strukturalista. Od 1962 pracownik Instytutu Badań Literackich PAN, od 1991 r. do śmierci członek Rady Fundacji na rzecz Nauki Polskiej, w latach 1994-1997 i 2000-2003 jej przewodniczący. Współzałożyciel a następnie współredaktor "Tekstów” (1972). Doktor honoris causa Uniwersytetu Łódzkiego (promotorem był prof. Grzegorz Gazda) i Katolickiego Uniwersytetu Lubelskiego.

27 Prof. Bogdan Zakrzewski (1916-2011), historyk literatury polskiej, badacz polskiego romantyzmu, znawca twórczości Aleksandra Fredry. Profesor Uniwersytetu Wrocławskiego. W latach 1960-1998 redaktor "Pamiętnika Literackiego".

28 Dr Jerzy Rozental (1930-1998), językoznawca, teoretyk literatury. Pracownik UŁ w latach 1957-1995, najpierw Zakładu Literatury Polskiej XIX w., następnie Katedry Teorii Literatury, zaś od 1988 r. Katedry Literatury Romantyzmu i Literatury Współczesnej.

29 Prof. dr hab. Stanisław Kaszyński (1926-1988) - historyk teatru i literatury, wieloletni (1969-1988) kierownik Katedry Dramatu i Teatru w Instytucie Teorii Literatury, Teatru i Filmu UŁ (dziś: Instytut Kultury Współczesnej).

30 Prof. dr Jan Dürr-Durski (1902-1969), historyk literatury polskiej. Pracownik UŁ od 1945 r., kierownik Katedry Literatury Polskiej i Zakładu Literatury Staropolskiej (od roku 1955). Prowadził badania z zakresu renesansu i baroku, wiele uwagi poświęcił również twórczości S. Wyspiańskiego.

31 Iwona Śledzińska-Katarasińska, działaczka polityczna, członkini Platformy Obywatelskiej (od 2001 r.), wielokrotna posłanka na sejm, dziennikarka. W 1963 r. ukończyła studia polonistyczne na Wydziale Filologicznym UŁ. 
IH: Czyli była różnica między formą ćwiczeń a konwersatoriów?

TC: Na pewno liczbowa - do trzydziestu osób na ćwiczeniach, do piętnastu na konwersatoriach. Wykłady zaczęłam prowadzić po doktoracie. I właściwie wtedy już zaczęłam zbierać materiały do habilitacji.

IH: Tej książki o powieści nowoczesnej?

TC: Tak, w tym fatalnym uniwersyteckim wydaniu...

IH: Takie były czasy - mocno siermiężne, sprzyjające bylejakości, trudne także dla wydawców: zły papier, miękkie okładki, standardowa typografia.

Pamiętam też moment, kiedy robiła Pani habilitację.

TC: To było w 1974 roku, w 1975 roku dostałam nominację na profesora nadzwyczajnego, w 1990 roku - uzwyczajnienie.

IH: Ale wcześniej chyba Pani Profesor przez moment była docentem, prawda?

TC: Tak. Stopień docenta był powszechnie stosowany w uczelniach, ale później zaczęto go wykorzystywać nie merytorycznie, lecz politycznie. Do czasu mojej habilitacji zachowało się jeszcze to tzw. „marcowe” nazewnictwo.

IH: Utkwiło mi to w pamięci, bo kiedy będąc pod opieką Pani Profesor - miałam indywidualny program studiów - przyszłam do Instytutu, z siedzibą jeszcze $w$ kilku salach Biblioteki Uniwersyteckiej, weszłam do pokoju 123 z pytaniem, czy jest pani doktor Cieślikowska, Sławek Orlicki ${ }^{32}$ powiedział „pani docent Cieślikowska!" I tak dowiedziałam się o habilitacji Pani Profesor.

Ale w związku z problematyką Pani rozprawy habilitacyjnej chciałam jeszcze zapytać, czy profesor Skwarczyńska sugerowała Państwu tematykę lub kierunek badań?

TC: Nie, problematykę badań wybieraliśmy swobodnie, ale ona bardzo troskliwie dbała o to, żeby każdy $\mathrm{z}$ zatrudnionych pracował $\mathrm{w}$ podjętym przez siebie kierunku. Ja tej opieki doświadczyłam w olbrzymim stopniu; troskliwości, pilnowania terminów...

IH: Do dzisiaj powtarzana jest taka opinia o profesor Skwarczyńskiej - że była niezwykle wymagająca, ale równoważyła to gestami przyjaźni, opieki. Sama pamiętam jeszcze ten czas, kiedy Pani Profesor przygotowywała przed Wigilią dla wszystkich pracowników prezenty w postaci książek. Każdy dostawał tom $\mathrm{z}$ adresowaną specjalnie do niego, własnoręcznie pisaną, acz podpisaną przez św. Mikołaja, dedykacją.

Ciekawi mnie więc, jak Pani odniosłaby się do zdania pani profesor Karwackiej $^{33}$, z którą rozmowa ukazała się w trzecim numerze "Czytania Literatury", że w odróżnieniu od katedry polonistycznej prowadzonej

32 Dr Sławomir Orlicki (1948-2011), teoretyk literatury (znawca eseju), dziennikarz. Do lat dziewięćdziesiątych XX w. adiunkt w Katedrze Teorii Literatury w Instytucie Teorii Literatury, Teatru i Filmu (dziś: Instytut Kultury Współczesnej) Uniwersytetu Łódzkiego.

33 Prof. dr hab. Helena Karwacka, historyk literatury (zwł. Literatury polskiej XX w.). W latach 1954-1979 związana z Uniwersytetem Łódzkim. Tutaj uzyskała habilitację (1969) oraz tytuł profesorski (1977). Od roku 1972 pełniła funkcję prodziekana Wydziału Filologicznego. W 1974 objęła kierownictwo Zakładu Literatury Współczesnej. W latach 1979-2000 pracowała w Instytucie Filologii Polskiej Uniwersytetu Warszawskiego oraz w Filii UW w Białymstoku. 
przez profesora Skwarczyńskiego, gdzie zawsze było mało sympatycznie, u teoretyków literatury profesor Skwarczyńska stworzyła bardzo miłą atmosfere. Czy faktycznie tak było?

TC: Wydaje mi się, że Profesor Skwarczyńska chciała, by w katedrze panowała rodzinna atmosfera i umiała o to zadbać od samego początku. Owszem, pamiętam jeden niemiły przypadek, zupełnie jednostkowy, ale żadnych konfliktów, sporów, zatargów sobie nie przypominam.

IH: A organizowało się spotkania nie naukowe, lecz stricte towarzyskie, lub może zebrania naukowe przekształcały się niepostrzeżenie w jakieś nieformalne „wieczorki"?

TC: Nie, jeśli miały kiedyś miejsce jakieś takie zdarzenia, to dokonywały się raczej spontanicznie, w sposób nieregulowany. Żadnych formalnych spotkań towarzyskich nie było, chyba że przy konferencjach - wówczas tak, zawsze. Natomiast zdarzały się nieformalne dyskusje czy spory, pewnie nie tylko naukowe, ale nie dotyczyły niczego szczególnego, nie przekształcały się w kłótnie i trwałe zatargi. Oczywiście nie jestem w stanie o tym zapewnić, być może nie wiedziałam o czymś, może na pewne rzeczy byłam ślepa.

IH: Jak każdy...

TC: Jeśli zastanawiam się nad poważniejszymi nieporozumieniami, to przychodzi mi na myśl kwestia teorii literatury, która stanowiła przedmiot częstych sporów między polonistyką a nami. Przyczyny praktyczne, takie choćby jak miejsce teorii literatury w planie studiów polonistycznych, przesłaniają różnice $\mathrm{w}$ rozumieniu tego, czym teoria literatury powinna być, a czym praktycznie była. Także na skutek zawężenia wiedzy między dyscyplinami porozumienie jest bardzo utrudnione. To pozostało. A rozpoczęło się wcześniej, kiedy zaczęły dominować skutki teorii Derridy. Kiedy czytałam rozmaite rozprawy z różnych konferencji, robiło mi się przykro, gdy widziałam, jak ludzie dopasowują się do czegoś, co było dla mnie jeszcze jedną wersją komunistycznych pomysłów i działań, które podskórnie weszły do teorii literatury i zaczęły burzyć wszystko.

IH: Profesor Skwarczyńska była postrzegana jako osoba nadzwyczaj sroga, podobno młodsi pracownicy wręcz bali się jej.

TC: Ja nigdy nie miałam takich odczuć. Wiedziałam, że trzeba pilnować rygoru i dla mnie to było oczywiste. Na mnie się to nie odbiło, choć może... do pewnego stopnia. Profesor Skwarczyńska była w najwyższym kierownictwie PAXu, a mój mąż był antagonistą tej instytucji, nawet coś kiedyś napisał w związku z tym. Ta sytuacja była dla mnie przykra, niemniej nie moge powiedzieć, że odczuwałam jakiś lęk wobec konieczności spotkania z Panią Profesor. Słyszę też, przez moją wnuczkę, że moi studenci bardzo bali się mnie. Nie wiem, dlaczego. Może za dużo postawiłam dwójek?

IH: Ja z kolei nie zapomnę, że kiedy pierwszy raz egzaminowałyśmy, Danka $^{34}$ i ja, razem z Panią Profesor z teorii literatury, studenci ustawiali się w długiej kolejce do Pani, bo nas się bali, byłyśmy wtedy wyjątkowo

34 Dr hab. prof. UŁ Danuta Szajnert, teoretyk literatury, autorka rozprawy Intencja autora i interpretacja - między inwencja a atencją. Teksty i parateksty (2011). Od roku 1976 najpierw asystent, potem adiunkt w Katedrze Teorii Literatury w Instytucie Kultury Współczesnej (d. Instytut Teorii Literatury, Teatru i Filmu) Uniwersytetu Łódzkiego. 
srogie. Ale wydaje mi się, że podstawową przyczyną tych obaw wobec egzaminatorów były jednak legendy o tym, że teoria literatury jest najtrudniejszym przedmiotem na studiach.

TC: No, nie wiem... Była taka historia, ale nie chcę, żeby pani to źle odebrała, o której powiedziała mi Danka, że ja odstraszyłam studentkę, którą ona widziała jako dobrą kandydatkę do różnych teoretycznoliterackich awansów. A ja ją źle potraktowałam. Przyjęłam to, bo uważam Dankę za świetnego dydaktyka i osobę bardzo sprawiedliwą. Taki fakt miał miejsce, że kogoś zniechęciłam.

IH: Ale skoro Pani zapamiętała to zdarzenie, to takie przypadki musiały być bardzo sporadyczne. Spokojnie można dojść do wniosku, że najbardziej straszyła ich sama teoria literatury.

TC: Pewnie tak.

IH: A czy słyszała Pani Profesor, że kilka lat temu studenci polonistyki stworzyli neologizm "terroria literatury"?

TC: Może przyczyniłam się do tego...

IH: Nie przypuszczam. Wydaje mi się natomiast, że trudność zrozumienia teorii polega głównie na konieczności zastosowania zupełnie innego sposobu myślenia, niż to, którym studenci posługują się przy zadaniach z historii literatury. Dzisiejsi studenci mają - a to z powodu zmian, by nie rzec, radykalnych zmian w programach studiów - za słabe zaplecze czy to filozoficzne, czy psychologiczne, a przecież nadal omawiamy kierunki i szkoły badawcze wyrosłe z tych dyscyplin.

TC: Tu mi pani przypomniała Wyższą Szkołę Humanistyczno-Ekonomiczną...

IH: Tak jest również na naszych studiach uniwersyteckich, bezpłatnych. Myślę, że to wynik tego, że szkoła jest dzisiaj zupełnie inna.

TC: Szkoły w ogóle nie ma, po tych wszystkich zmianach.

IH: Tak, cztery godziny polskiego tygodniowo w liceum...

TC: Dla mnie z kolei ograniczenie historii jest sprawą katastrofalną...

IH: I brak egzaminów wstępnych na studia. Przecież żeby dostać się na filologię polską czy na kulturoznawstwo, należało zdać egzaminy nie tylko z języka polskiego i obcego, ale właśnie z historii. $W$ tamtym czasie można było tworzyć programy studiów odwołując się do znacznie głębszej i szerszej wiedzy przyszłych studentów. Czy tak powstawał pierwszy program kulturoznawstwa? Profesor Skwarczyńska zaczęła myśleć o niezależnym kierunku studiów na początku lat siedemdziesiątych chyba, prawda?

TC: Tak. Wcześniej nie było formalnych możliwości, by Katedra Teorii Literatury samodzielnie prowadziła kierunek. Na szczęście udało się stworzyć katedrę z trzema zakładami. Najpierw doszło do fuzji z filmoznawstwem - ponieważ $w$ tym czasie Lewicki ${ }^{35}$ był już profesorem, więc

35 Prof. Bolesław Włodzimierz Lewicki (1908-1981), teoretyk filmu (autor Wprowadzenia do wiedzy o filmie, 1964), krytyk. Od 1959 kierownik Zakładu Wiedzy o Filmie, potem Katedry Wiedzy o Filmie, także dyrektor Instytutu Teorii Literatury, Teatru i Filmu UŁ; profesor (1970) i rektor (1968-1969) Państwowej Wyższej Szkoły Teatralnej i Filmowej w Łodzi. 
nie istniały w tym względzie przeszkody natury formalnej. Dopiero potem

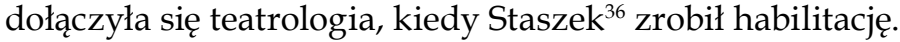

IH: Katedra była nadal jedna, ale $\mathrm{z}$ trzema zakładami?

TC: Tak, inaczej niż teraz.

IH: Cóż, teraz mamy po prostu bardziej złożoną strukturę: instytut, w nim katedry, w katedrach zakłady, w tych czasem jeszcze pracownie.

TC: No tak. Katedra też przecież przestała być katedrą a została instytutem. To był chyba 1973 rok, a kulturoznawstwo powołano troszeczkę później. Myślę, że to jeszcze troszeczkę trwało, zanim udało się doprowadzić do powstania nowego kierunku, bo to nie było łatwe.

IH: A program kulturoznawstwa? Czy wszyscy pracownicy uczestniczyli w jego przygotowywaniu?

TC: Tak, raczej tak. Ja opracowywałam program teorii literatury dla kulturoznawstwa i filologii polskiej.

IH: One się różniły?

TC: Na pewno, bo musiały wejść inne zajęcia, może ćwiczenia, a na pewno wykłady.

IH: Na kulturoznawstwie prowadziliśmy też sporo zajęć z historii literatury. Zapewne pamięta Pani Profesor, że od początku mieliśmy historię literatury powszechnej? Cztery semestry zajęć, wykładów i ćwiczeń, których program obejmował naprawdę literaturę światową, nawet takie egzotyczne zjawiska jak na przykład poezja malajska. Ja tutaj do Państwa, do męża Pani Profesor przychodziłam dokształcać się z literatury staroindyjskiej.

TC: Te historycznoliterackie zajęcia $\mathrm{z}$ teorii literatury były bardzo potrzebne.

IH: Domyślam się więc, że przyczyniła się Pani do uwzględnienia ich w programie kulturoznawstwa i wypełnienia tak bogatą treścią?

TC: Tak, dążyłam do tego, by nasi studenci mieli jak najwszechstronniejszą wiedzę.

IH: W latach siedemdziesiątych na polonistyce też były zajęcia z literatury powszechnej. Ich program był jednak skupiony na literaturach europejskich i nie obejmował XX wieku. Przyznam, że prowadzac ćwiczenia na kulturoznawstwie sama nieustannie musiałam się uczyć, ale choć było to dużym obciążeniem, dawało też mnóstwo przyjemności.

TC: Wiem, że Bożena ${ }^{37}$ była bardzo na mnie zła za to, że powierzyłam jej wykład.

IH: Zatem kulturoznawstwo powstało w 1976 roku, czyli już za kierownictwa Pani Profesor.

Tak. Zakład prowadziłam od 1973 roku, a w roku 1981 objęłam dyrekcję Instytutu Teorii Literatury, Teatru i Filmu, w którego nazwie później na moją propozycję przywrócono określenie „katedra”. To było w 1991 roku, i tak zostało do 1997 roku, do mojej emerytury.

36 Profesor Stanisław Kaszyński.

37 Dr Bożena Marczewska, teoretyk literatury (znawca problematyki powieści warsztatowej), w latach siedemdziesiątych i osiemdziesiątych XX w. adiunkt w Katedrze Teorii Literatury w Instytucie Teorii Literatury, Teatru i Filmu (dziś: Instytut Kultury Współczesnej) UŁ. 
IH: Wiem, że Pani Profesor zżymała się na to określenie „instytut".

TC: Dla mnie instytuty były ciałem obcym, zupełnie. Produktem wschodnim.

IH: A jak wyglądał Instytut za kierownictwa Pani Profesor?

TC: Nadal były trzy zakłady - teorii literatury, dramatu i teatru oraz filmoznawstwa.

IH: Samodzielne?

TC: Formalnych ustaleń nie było. W praktyce każdy z nich zachował pewną niezależność, zwłaszcza naukową, specjalistyczną, co oczywiste.

IH: A czy ta współpraca między zakładami objawiała się wspólnymi inicjatywami? Czy na przykład organizowano wspólne konferencje?

TC: Konferencje tak, ale czy coś jeszcze?

IH: A wydawnictwa? Życie "Zagadnień Rodzajów Literackich" toczyło się swoim trybem. A co z tomami "Acta Universitatis Lodziensis. Folia Scientiae Artium et Litterarum"?

TC: Do „Zagadnień..." pisywali nie tylko literaturoznawcy, także pracownicy pozostałych zakładów. Natomiast "Acta..." wykorzystywaliśmy m.in. do publikowania studiów o awangardzie. Od końca lat osiemdziesiątych do połowy dziewięćdziesiątych ukazało się pięć tomów pod wspólnym tytułem $W$ kręgu zagadnień awangardy. To było duże przedsięwzięcie, również wymagające stałej współpracy między specjalistami ze wszystkich reprezentowanych $w$ Katedrze dziedzin.

Chcę też przypomnieć sprawę nadania sali na Sienkiewicza $21^{38}$ imienia Profesor Skwarczyńskiej - to też udało nam się wspólnie, jako Instytutowi, przeprowadzić. Sala im. Skwarczyńskiej powstała, jakkolwiek w pomieszczeniu, którym dysponowała Katedra Germanistyki.

IH: To miała być jednak aula wspólna, z której korzystaliby studenci wszystkich kierunków mających swoje siedziby na Sienkiewicza. My, pracownicy Instytutu Teorii Literatury, Teatru i Filmu, zorganizowaliśmy uroczystość, wmurowana została tablica, ale germaniści zaanektowali tę aulę dla siebie, nazywając ją zawsze salą Goethego, bo tam wisiał jego portret, i tak już zostało do końca, do czasów naszej przeprowadzki do Pałacu Biedermanna i później, do przenosin całego Wydziału Filologicznego do wspólnego gmachu na Pomorskiej. Tu natomiast dziekan zadecydowal, że nie będziemy mieć patronów, którzy by sygnowali poszczególne miejsca czy instytucje, bo mogłoby to doprowadzić do nieporozumień.

Myślę, że to dobra decyzja. Zresztą Pani Profesor chyba lepiej ode mnie zdaje sobie sprawę, jak trudno jest "rządzić a nie dzielić". Przecież objęła Pani dyrekcję Instytutu w trudnym politycznie momencie, w 1981 roku. Jak Pani to podźwignęła? Strajki, stan wojenny, zawieszenie działalności naukowej i dydaktycznej...

TC: No cóż, strajki się odbywały. Pamiętam, że przesiedziałam w nocy raz i drugi, w miłym gronie zresztą.

38 Jeden z adresów Instytutu Teorii Literatury, Teatru i Filmu (dziś: Instytut Kultury Współczesnej). W budynku tym mieściły się oprócz ITL, TiF Katedry Germanistyczne oraz Katedra Filologii Romańskiej. 
IH: Tak, bo to był okres, kiedy wszyscy bardzo starali się odnosić do siebie życzliwie, taka to zaleta "wybuchu stanu", mówiąc Białoszewskim.

TC: Były tego i praktyczne skutki, miałam raz wizytę z ulicy Lutomierskiej, ze Służby Bezpieczeństwa. Na koniec powiedziałam, że jeśli mają ochotę, mogą przyjść, zobaczyć, posłuchać. Wszystko odbywało się bardzo grzecznie, potem już nie przychodzili.

IH: Mimo że pracowali u nas Radek Tatarowski ${ }^{39}$ i Jacek Bartyzel ${ }^{40}$.

TC: Kiedy Radek chciał wziąć z Instytutu książki, miał jakieś utrudnienia, musiał dostawać pozwolenie...

IH: Na zakończenie naszej rozmowy chciałabym powrócić do wątku osobistego, jeśli Pani Profesor pozwoli, i zapytać o Pani aktualne lektury.

TC: Obecnie moje zainteresowania skupiają się na problematyce społeczno-publicystycznej.

Tekst opracowała: Agnieszka Kałowska

Przypisy opracowała: Irena Hübner

\section{STRESZCZENIE}

Teresa Cieślikowska, emerytowana profesor Uniwersytetu Łódzkiego, wybitna teoretyk literatury w rozmowie z Ireną Hübner opowiada o swoich studiach na łódzkiej polonistyce i pracy naukowej.

\section{Słowa kluczowe}

teoria literatury, łódzka polonistyka, Uniwersytet Łódzki

\section{S U M M A RY}

Theory (of literature) was something else. Professor Teresa Cieślikowska interviewed by Irena Hübner

39 Dr hab. prof. UŁ Konrad Tatarowski, teoretyk literatury, medioznawca, działacz polityczny. Od lat siedemdziesiątych XX w. do roku 1983 adiunkt w Katedrze Teorii Literatury w Instytucie Teorii Literatury, Teatru i Filmu (dziś: Instytut Kultury Współczesnej) Uniwersytetu Łódzkiego. Działacz Komitetu Obrony Robotników (od 1977 r.), współzałożyciel NSZZ "Solidarność" na Uniwersytecie Łódzkim, internowany 13 grudnia $1981 \mathrm{r}$. W $1983 \mathrm{r}$. wyemigrował z rodziną z paszportem w jedną stronę (1,5 roku w USA, 11 lat w Niemczech). W latach 1984-1994 współpracownik rozgłośni Radio Wolna Europa. Od 1994 roku ponownie zatrudniony na Uniwersytecie Łódzkim.

40 Prof. dr hab. Jacek Bartyzel, wykładowca akademicki, działacz społeczny, publicysta. W latach 1981-1986 asystent, w latach 1988-2004 adiunkt w Zakładzie Dramatu i Teatru Katedry (następnie Instytutu) Teorii Literatury, Teatru i Filmu UŁ. W latach 1976-1977 współpracował z Komitetem Obrony Robotników, następnie z KSS KOR. Od 1977 do 1979 działał w Ruchu Obrony Praw Człowieka i Obywatela. Od 1979 był współzałożycielem i rzecznikiem Ruchu Młodej Polski. Podczas stanu wojennego internowany. 
Teresa Cieślikowska, retired professor at the University of Łódź and a prominent theorist of literature talks to Irena Hübner about studying Polish Studies in Łódźand her academic career.

\section{Keywords}

literary theory, Polish Studies in Łódź, University of Łódź 